Article

\title{
Slope Position Rather Than Thinning Intensity Affects Arbuscular Mycorrhizal Fungi (AMF) Community in Chinese Fir Plantations
}

\author{
Xuelei Xu ${ }^{1,2}$, Xinjie Wang ${ }^{1}$, Michelle Cleary ${ }^{2}{ }^{\oplus}$, Ping Wang ${ }^{3}$, Nini Lu ${ }^{1}$, Yujun Sun ${ }^{1, *}$ and \\ Jonas Rönnberg ${ }^{2}$ \\ 1 State Forestry Administration Key Laboratory of Forest Resources \& Environmental Management, \\ College of Forestry, Beijing Forestry University, Beijing 100083, China; xuxuelei@bjfu.edu.cn (X.X.); \\ xinjiew@bjfu.edu.cn (X.W.); lunini2008@bjfu.edu.cn (N.L.) \\ 2 Southern Swedish Forest Research Centre, Swedish University of Agricultural Sciences, \\ 23053 Alnarp, Sweden; michelle.cleary@slu.se (M.C.); jonas.ronnberg@slu.se (J.R.) \\ 3 College of Grassland Science, Beijing Forestry University, Beijing 100083, China; wangping@bjfu.edu.cn \\ * Correspondence: sunyj@bjfu.edu.cn; Tel.: +86-136-4129-8548
}

Received: 20 January 2020; Accepted: 25 February 2020; Published: 28 February 2020

\begin{abstract}
Background and Objectives: Arbuscular mycorrhizal fungi (AMF) play a crucial role in individual plant capability and whole ecosystem sustainability. Chinese fir, one of the most widely planted tree species in southern China, forms associations with AMF. However, it is still unclear what impacts thinning management applied to Chinese fir plantations has on the structure and diversity of soil AMF communities. This research attempts to bridge this knowledge gap. Materials and Methods: A thinning experiment was designed on different slope positions in Chinese fir plantations to examine the impacts of slope position and thinning intensity on colonization, diversity, and community composition of AMF. Results: Our research showed that the altitudinal slope position had significant effects on colonization, diversity, and community composition of AMF in Chinese fir plantations. In addition, the interaction between slope position and thinning intensity had significant effects on AMF diversity. Colonization by AMF on the lower slope position was significantly higher than on the upper slope position, while AMF diversity on the upper slope position was higher than on the middle and lower slope positions. Glomus was the most abundant genus in all slope positions, especially on the middle and lower slope positions. The relative abundance of Diversispora was significantly different among slope positions with absolute dominance on the upper slope position. Scutellospora was uniquely found on the upper slope position. Furthermore, soil Mg and Mn contents and soil temperature positively affected AMF community composition at the operational taxonomic unit (OTU) level. Conclusions: These findings suggested that slope position should be considered in the management of Chinese fir plantations. Furthermore, both chemical fertilization and AMF augmentation should be undertaken on upper hill slope positions as part of sustainable management practices for Chinese fir plantations.
\end{abstract}

Keywords: slope position; thinning intensity; Chinese fir plantations; arbuscular mycorrhizal fungi $(\mathrm{AMF})$; soil properties

\section{Introduction}

Chinese fir (Cunninghamia lanceolata) is one of the most important fast-growing tree species with high production and outstanding timber quality that has been extensively planted in southern China to satisfy the increasing requirement for wood production [1]. It is estimated that the total area of Chinese fir plantations in China is approximately 8.95 million ha [2], and they play a vital role in 
both timber production and ecosystem maintenance. In such production forests, growth has not been satisfactorily uniform, although the area of the plantations has increased substantially in recent decades $[3,4]$. This is because most plantations were initially planted at high density and have not been efficiently managed with thinning $[1,5,6]$. In addition, these plantations may exhibit other problems associated with monocultures [3,7], such as simple community structure, lack of biological stability, litter decomposition tardiness, and soil nutrient and land fertility losses [4,8,9], which seriously affect the long-term productivity and sustainable management of the plantations $[8,10,11]$.

Thinning, as an important silvicultural practice, affects forest characteristics directly and indirectly, such as overstory, understory, soil properties [1,12,13], and microbial communities [14,15]. Several studies have shown that the development of understory after thinning results in an increasing proportion of rapidly decomposable litter, which could supplement the available soil nutrients [16-18] and ultimately affect the soil microorganisms because of the variety of litter, plant roots, and exudates [12,19-21]. In turn, soil microorganisms may influence the growth of plants by altering elements in the rhizosphere soil and improving nutrient acquisition by plants [20,22]. Hence, it is necessary to understand the changes of soil microorganisms and the relational soil factors in forest thinning practice [15,23-25].

Slope position, as an important topographical factor, is responsible for the heterogeneity of the microenvironment by changing the light, temperature, and water [26]. Slope position affects soil structure and development $[27,28]$, soil nutrient redistribution and availability by gravity and hydraulic power [29,30], and diversity and distribution of vegetation [31-33] and soil microbes [34-36]. Given the significance of slope position to individuals, communities, and ecosystems [30,36,37], the influence of slope position on growth and community of vegetation and soil properties has been extensively investigated [27,37-39]. In the hilly areas of southern China, previous studies have shown that the slope position significantly influences the growth of Chinese fir [40] and vegetation structure $[31,32,41]$. However, the impacts of slope position on belowground microbial communities remain poorly understood.

As a fundamental soil microbial component, arbuscular mycorrhizal fungi (AMF), belonging to the subphylum Glomeromycotina [42], are the most common type of mycorrhizal fungi and form mycorrhizal symbioses with $80 \%$ of all terrestrial plant species [43-45]. AMF have beneficial impacts on individual plant capability, including increasing nitrogen $(\mathrm{N})$ and phosphorus $(\mathrm{P})$ acquisition $[44,46,47]$, improving tolerance to drought [48] and salt stress [49], and enhancing pathogen resistance of host plants [50,51]. Furthermore, AMF play a crucial role in ecosystem sustainability [51,52] by regulating the rhizosphere microbial community composition [53], soil structure, and nutrient cycling [54-56]. Given the important role of AMF in individual plants and ecosystem function, several studies have investigated the spore density, root colonization, abundance, and community of AMF using a taxon-based approach [45,57-59]. The majority of these studies, however, have focused on agriculture and grassland systems, and few studies have been undertaken to examine the effects of slope position on AMF spore density, root colonization, and abundance using a taxon-based approach, especially in forests [24,26]. The results of these studies are far from unequivocal, and the environmental factors associated with slope position that influence AMF assemblages have not been identified.

Chinese fir has been reported to form associations with AMF $[60,61]$. However, research on AMF in Chinese fir plantations is extremely scarce. It is still unclear what impacts thinning management has on the colonization, diversity, and community composition of AMF in Chinese fir on different slope positions and thinning intensities, especially in hilly areas. Colonization by AMF would promote nutrient absorption of Chinese fir, thereby improving growth [61,62]. In addition, different AMF species and community composition play important roles in the performance of host plants, enriching soil microbial communities, promoting nutrient cycling, and improving the function of ecosystems. Thus, in this study, we chose Chinese fir plantations located in southeastern China to examine the impacts of slope position and thinning intensity on the occurrence, diversity, and community composition of AMF. We hypothesized that both slope position and thinning intensity would affect the colonization, diversity, 
and community composition of AMF, which would be closely related to changing microclimate and edaphic factors. In order to test this hypothesis, the thinning experiment was designed across a gradient of slope positions to determine AMF community composition. Our specific aims were as follows: (1) test the effects of slope position and thinning intensity on AMF colonization and diversity; (2) evaluate AMF community composition and distribution pattern among different slope positions and thinning intensities; and (3) discover the most important topographical and edaphic factors affecting the AMF community compositions and distributions.

\section{Materials and Methods}

\subsection{Study Area and Site Description}

The study area $\left(26^{\circ} 26^{\prime}-27^{\circ} 04^{\prime} \mathrm{N}, 117^{\circ} 05^{\prime}-117^{\circ} 40^{\prime} \mathrm{E}\right)$ is located in the Jiangle National Forest Farm in Jiangle County, Fujian Province, Southeast China (Figure 1). The climate in this region is a subtropical monsoon climate. The annual average temperature is $19.5{ }^{\circ} \mathrm{C}$ and the annual average precipitation is $1665 \mathrm{~mm}$. This region is dominated by low-mountain hilly terrain with an altitude ranging between 200 and $800 \mathrm{~m}$, and the soil is identified as an Ultisols (commonly known as red clay soils) following the USDA Soil Taxonomy. The dominant tree species are Chinese fir (C. lanceolata) and Masson pine (Pinus massoniana). The prominent understory species include beautyberry (Callicarpa giraldii), Ficus simplicissima (Ficus hirta), Blechnoid (Blechnum orientale), Stenoloma chusana (Stenoloma chusanum), Dicranopteris pedata (Dicranopteris dichotoma), and chain fern (Woodwardia japonica).

The study area is dominated by Chinese fir plantations planted in 2005, and the total area is 3 ha with similar site quality. Before thinning, the average diameters at breast height (DBH) and tree height were $12.83 \mathrm{~cm}$ and $8 \mathrm{~m}$, respectively. The average tree density was $2967 \mathrm{stem} \mathrm{ha}^{-1}$, the stand basal area was $38.00 \mathrm{~m}^{2} \mathrm{ha}^{-1}$, and the stand volume was $198.07 \mathrm{~m}^{3} \mathrm{ha}^{-1}$. The thinning experiments were initially established in May 2013 when the trees were 8 years old. Five thinning treatments were conducted with the removal of approximately 0 (control), 20\%, 25\%, 33\%, and 50\% of trees, respectively. After thinning, the average DBH and tree height were $13.08 \mathrm{~cm}$ and $9.1 \mathrm{~m}$, respectively, the average residual density ranged between 1600 and 2967 stem ha $^{-1}$, the stand basal area was $29.96 \mathrm{~m}^{2} \mathrm{ha}^{-1}$, and the stand volume was $169.93 \mathrm{~m}^{3} \mathrm{ha}^{-1}$. Three replicate plots were established within each thinning intensity in the upper (US), middle (MS), and lower (LS) slope positions in August 2013 (Figure 1, Table 1).

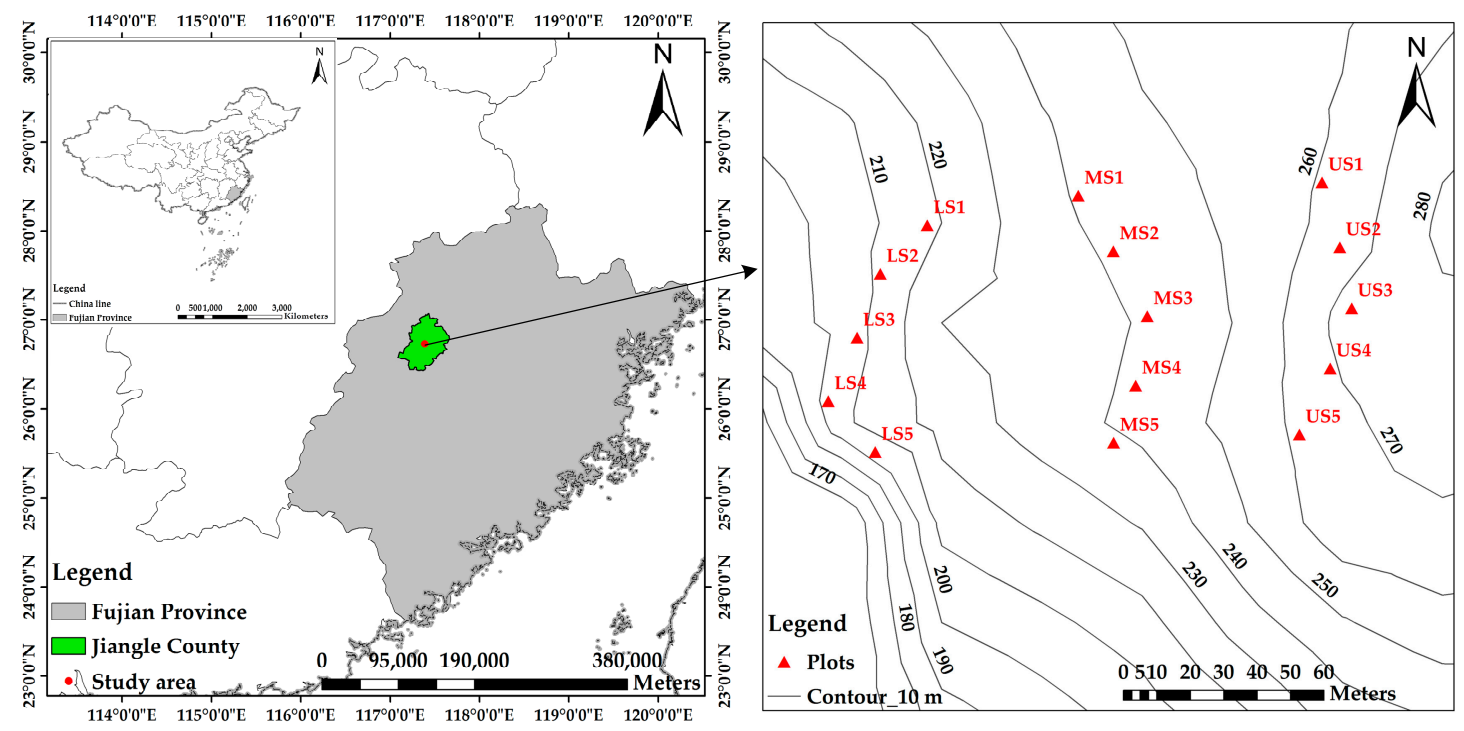

Figure 1. Location of study area and plot distribution. 
Table 1. Basic conditions of plots.

\begin{tabular}{|c|c|c|c|c|c|c|c|c|c|c|}
\hline Plots & $\begin{array}{l}\text { Plot } \\
\text { Area } \\
\left(\mathrm{m}^{2}\right)\end{array}$ & $\begin{array}{l}\text { Slope } \\
\text { Position }\end{array}$ & Aspect & Slope & $\begin{array}{l}\text { Altitude } \\
\text { (m) }\end{array}$ & $\begin{array}{l}\text { Thinning } \\
\text { Intensity }\end{array}$ & $\begin{array}{c}\text { Reserved } \\
\text { Tree Density } \\
\left(\text { Stem ha }{ }^{-1}\right)\end{array}$ & $\begin{array}{l}\text { Mean } \\
\text { DBH } \\
(\mathrm{cm})\end{array}$ & $\begin{array}{c}\text { Mean } \\
\text { Tree } \\
\text { Height } \\
\text { (m) }\end{array}$ & $\begin{array}{c}\text { Canopy } \\
\text { Density } \\
(\%)\end{array}$ \\
\hline US1 & $15 \times 20$ & Upper & $247^{\circ}$ & $34^{\circ}$ & 261.6 & $25 \%$ & 2300 & 12.4 & 9.5 & 70 \\
\hline US2 & $15 \times 20$ & Upper & $296^{\circ}$ & $31^{\circ}$ & 265.1 & $50 \%$ & 1500 & 12.1 & 8.5 & 50 \\
\hline US3 & $15 \times 20$ & Upper & $311^{\circ}$ & $32^{\circ}$ & 271.5 & $0 \%$ & 2900 & 11.8 & 10.0 & 88 \\
\hline MS1 & $15 \times 20$ & Middle & $314^{\circ}$ & $31^{\circ}$ & 240.5 & $25 \%$ & 2267 & 13.9 & 9.0 & 69 \\
\hline MS2 & $15 \times 20$ & Middle & $303^{\circ}$ & $39^{\circ}$ & 242.5 & $50 \%$ & 1667 & 13.4 & 8.5 & 52 \\
\hline MS3 & $15 \times 20$ & Middle & $310^{\circ}$ & $31^{\circ}$ & 241.8 & $0 \%$ & 2933 & 12.8 & 9.9 & 89 \\
\hline MS4 & $15 \times 20$ & Middle & $300^{\circ}$ & $33^{\circ}$ & 242.6 & $33 \%$ & 2033 & 12.9 & 9.4 & 65 \\
\hline MS5 & $15 \times 20$ & Middle & $346^{\circ}$ & $32^{\circ}$ & 238.4 & $20 \%$ & 2500 & 12.2 & 8.8 & 73 \\
\hline LS4 & $20 \times 20$ & Lower & $296^{\circ}$ & $33^{\circ}$ & 202.3 & $33 \%$ & 2125 & 13.6 & 9.9 & 65 \\
\hline LS5 & $20 \times 20$ & Lower & $292^{\circ}$ & $31^{\circ}$ & 202.9 & $20 \%$ & 2375 & 13.2 & 8.2 & 70 \\
\hline
\end{tabular}

US: upper slope position; MS: middle slope position; LS: lower slope position; DBH: diameter at breast height.

\subsection{Plot Investigation and Sampling}

Surveys were carried out in each plot and tracked every year after thinning. The DBH of individual trees was measured with a DBH tape. Individual tree volume was calculated using the following equation [63]:

$$
\mathrm{V}=0.0000872 D B H^{1.785388607} *[92.856-10186.041 /(D B H+107.907)]^{0.9313923697} .
$$

The stand volume of each plot was calculated as the sum of all individual trees. The average annual increment for stands in each plot was calculated using the following formula:

$$
\mathrm{Z}=\left(y_{t}-y_{t-n}\right) / n
$$

where $\mathrm{Z}$ is the average annual increment, $\mathrm{n}$ is the number of years between measurements, $y_{t}$ is the measure (quadratic mean diameter or volume) in years $t$, and $y_{t-n}$ is the measure in years $t-n$.

Intensive surveys were conducted in May 2015. Six sample trees were chosen randomly as the research objects in each plot, and 90 trees were finally selected. The fine roots with potential AMF and rhizosphere soil (at $10 \mathrm{~cm}$ depth) were collected for each sample tree from four directions (east, south, west, and north), and then mixed for subsequent analysis. Finally, 90 root samples and 90 soil samples were obtained. After collection, the root samples were stored at $-20^{\circ} \mathrm{C}$ for later colonization measurement and DNA extraction of AMF. The soil samples were transported to the laboratory for further processing.

\subsection{Mycorrhizal Colonization Measurement}

Roots were cut into 1-2 cm length segments and washed carefully with distilled water. The root segments were bleached by $10 \% \mathrm{KOH}$ solution with a few drops of $\mathrm{H}_{2} \mathrm{O}_{2}$ and water-bath heating at $90{ }^{\circ} \mathrm{C}$ for $2 \mathrm{~h}$, acidified with $1 \% \mathrm{HCl}$ for $15 \mathrm{~min}$, and stained in Trypan blue $(0.05 \%$ in 5:1:1 lactic acid/glycerol/distilled water) at $90{ }^{\circ} \mathrm{C}$ for $15 \mathrm{~min}$ using the method described by Zhang et al. [64]. Stained roots were then rinsed and decolorized by soaking in clean water overnight. To identify root colonization, root segments were prepared on glass slides, pressed lightly, and observed under the microscope at 200× magnification using the magnified intersection method [65]. In total, 10 root segments were randomly chosen per root sample and 10 fields of view of the microscope were observed for each root segment. Therefore, 100 intersects were measured to note whether the root was colonized 
by AMF at each intersection between the microscope vertical eyepiece crosshair and the roots. The AMF colonization rate was estimated as the percentage of root colonized.

\subsection{DNA Extraction, PCR Amplification, and Illumina Sequencing}

We chose 20 root segments from each root sample, which were cut into $1 \mathrm{~cm}$ length and washed carefully with distilled water. DNA was extracted from each root sample by the hexadecyltrimethylammonium bromide (CTAB) method [66]. We extracted a total of 90 genomic DNA samples in this study. Specifically, the mycorrhizal roots were ground with $300 \mu \mathrm{L}$ of $65{ }^{\circ} \mathrm{C}$ $2 \times$ CTAB extracting solution and moderately sterilized quartz sand. Next, samples were incubated in a $65{ }^{\circ} \mathrm{C}$ water bath for $1 \mathrm{~h}$, shaking (once every $15 \mathrm{~min}$ ) to fully dissolve the samples. Afterward, chloroform/isoamyl alcohol (24:1) solution was added and vortexed, and then the mixture was centrifuged at $12,000 \times \mathrm{g}$ at $25^{\circ} \mathrm{C}$ for $15 \mathrm{~min}$. The supernatant was then transferred to a new centrifuge tube carefully and centrifuged with chloroform/isoamyl alcohol (24:1) solution at $12,000 \times g$ at $4{ }^{\circ} \mathrm{C}$ for $15 \mathrm{~min}$. Then, the supernatant was transferred to a new centrifuge tube, and $30 \mu \mathrm{L} 5 \mathrm{M}$ potassium acetate (KAC) and $200 \mu \mathrm{L}$ of isopropyl alcohol were added and vortexed. After being kept overnight at $-20{ }^{\circ} \mathrm{C}$, the samples were centrifuged at $9200 \times g$ for $2 \mathrm{~min}$ at $4{ }^{\circ} \mathrm{C}$, and the liquid phase was discarded. The DNA pellet was washed with 70\% ethanol twice and dried using a SpeedVac®)device (AES 1010; Savant, Holbrook, NY, USA). Finally, a $65 \mu \mathrm{L}$ amount of deionized sterile water was added to dissolve the DNA sample at room temperature, and samples were stored at $-20^{\circ} \mathrm{C}$.

The partial small subunit (SSU) region of $18 \mathrm{~S}$ rRNA was amplified by nested PCR [67]. GeoA2 (5'CCAGTAGTCATATGCTTGTCTC3') [68] and AML2 (5'GAACCCAAACACTTTGGTTTCC3') [69] were used as the primers in the first amplification, whereas NS31 (5'TTGGAGGGCAAGTCTGGTGCC3') [70] and AMDGR (5'CCCAACTATCCCTATTAATCAT3') [71] were used in the second amplification. A 12 bp unique barcode was added at the $5^{\prime}$-end of NS31 in each sample; therefore, each sample has a unique identification (Table S1, Supplementary Materials). The first amplification was mixed with $12.5 \mu \mathrm{L}$ PCR MasterMix, $1 \mu \mathrm{L}$ GeoA2, $1 \mu \mathrm{L}$ AML2, and $2 \mu \mathrm{L}$ 1/20 $\times$ DNA, finally forming a $25 \mu \mathrm{L}$ reaction solution. The reaction started with a pre-denaturation at $94{ }^{\circ} \mathrm{C}$ for $3 \mathrm{~min}$, and then 29 cycles of denaturation at $94{ }^{\circ} \mathrm{C}$ for $30 \mathrm{~s}$, annealing at $48^{\circ} \mathrm{C}$ for $1 \mathrm{~min}$, extension at $72{ }^{\circ} \mathrm{C}$ for $3 \mathrm{~min}$, and final extension at $72{ }^{\circ} \mathrm{C}$ for $10 \mathrm{~min}$. The first amplification product was diluted $1 / 100$ with sterilized deionized water. The second amplification was performed according to the following cycling: $94{ }^{\circ} \mathrm{C}$ for $3 \mathrm{~min}, 29$ cycles at $94{ }^{\circ} \mathrm{C}$ for $45 \mathrm{~s}$, annealing at $45^{\circ} \mathrm{C}$ for $45 \mathrm{~s}, 72{ }^{\circ} \mathrm{C}$ for $1 \mathrm{~min}$, and $72{ }^{\circ} \mathrm{C}$ for $10 \mathrm{~min}$.

The PCR products (around $280 \mathrm{bp}$ ) were run on $1 \%$ agarose gel with $1.0 \times$ TAE buffer using gel electrophoresis, and visualized using GelRed ${ }^{\mathrm{TM}}$ (Biotium) Stain on a UV transilluminator (WD-9406, Beijing Liuyi Biotechnology, Beijing, China). Two PCR products (50 $\mu \mathrm{L})$ were pooled together for purifying to reduce potential early-round PCR errors, purified using an Axygen PCR Product Gel Purification Kit (Axygen, Union City, CA, USA) and quantified using a NanoDrop 8000 (Thermo Scientific, Wilmington, DE, USA). The purified products were mixed at equimolar concentrations to ensure that all samples were sequenced at the same level and then sequenced on an Illumina MiSeq platform (Illumina, San Diego, CA, USA) at the Environmental Genome Platform of the Chengdu Institute of Biology.

\subsection{Sequence Data Processing}

After sequencing, the paired-end reads were assembled by FLASH (version 1.2.8) [72]. All reads were assembled to each sample based on the unique barcodes. Sequences that did not contain the PCR primers, were longer than $300 \mathrm{bp}$, and had an average quality score $>30$ were retained for further analysis [67]. FASTA files were spliced and quality-filtered, and chimeras were removed using QIIME (version 1.17) [73]. The remaining non-chimera sequences were clustered into operational taxonomic units (OTUs) with UPARSE at a 97\% identity threshold [74] using the MaarjAM database as the reference [75]. The representative sequences were uploaded to the NCBI (National Center for Biotechnology Information) database and assigned by blasting against the SILVA database [76] 
according to a $97 \%$ sequence similarity. OTUs are presumed to be the level of "species". The OTUs not labeled as "Glomeromycotina" and with $<5$ reads were removed to reduce the risk of sequencing errors. The Glomeromycotina sequences were resampled to eliminate the effects of different read numbers. Afterward, to further confirm the remaining OTUs belonging to AM fungi, a phylogenetic tree was constructed in MEGA v7 (Kumar, Stecher, Li, Knyaz, and Tamura 2018) using the Kimura 2 parameter model with 1000 replicates, according to the representative sequences and reference sequences of Glomeromycotina downloaded from GenBank and MaarjAM [64]. Similar OTUs were merged and renumbered to produce a final OTU table for subsequent ecological analysis. The references were chosen only if they met the following criteria: BLAST score $>250$, query coverage $>97 \%$, and similarity between OTU and reference $>97 \%$.

\subsection{Soil Chemical Property Measurement}

All soil samples were air-dried and sieved (less than $2 \mathrm{~mm}$ ) to measure the soil chemical properties according to the method described by Bao [77]. The soil/water (1:5 w/v) suspensions were stirred for $30 \mathrm{~min}$ to measure soil $\mathrm{pH}$ utilizing a pH meter (PHS-2F, LEICI, Shanghai, China). Soil organic carbon (SOC) was estimated using an elemental analyzer (FLASH 2000 CHNS/O, Thermo Scientific, Wilmington, DE, USA). Soil total nitrogen (TN) and total phosphorus (TP) were determined using an AA3 continuous flow analytical system (AA3, SEAL, Norderstedt, Germany) after wet digestion with $\mathrm{HClO}_{4}-\mathrm{H}_{2} \mathrm{SO}_{4}$. Soil total magnesium $(\mathrm{Mg})$ and manganese $(\mathrm{Mn})$ contents were measured by an atomic absorption spectrometer (TAS-990AFG, Beijing Purkinje General, Beijing, China) after digesting with $\mathrm{HNO}_{3}-\mathrm{HClO}_{4}$. Soil available nitrogen (AN) was determined using the alkali solution diffusion method. Soil available phosphorus (AP) and available potassium (AK) were determined by a spectrophotometer (UV-2600, SHIMADZU, Kyoto, Japan) after $\mathrm{HCl}-\mathrm{NH}_{4} \mathrm{~F}$ extraction and ammonium acetate extraction, respectively. Soil temperature was measured by a digital thermometer (DT-131, CEM, Shenzhen, China) in the field.

\subsection{Statistical Analysis}

A two-way analysis of variance (ANOVA) was used to assess the differences of AMF colonization and diversity (including richness, Shannon-Wiener index, and Faith's phylogenetic diversity) among different slope positions (three levels) and thinning intensities (five levels) as well as their interaction, with the multiple comparisons of Tukey's HSD test at $p<0.05$. AMF richness referred to the number of OTUs per sample. The Shannon-Wiener index was calculated from the OTU relative abundances [78]. Richness and the Shannon-Wiener index were calculated using the "vegan" package in $R$, and Faith's phylogenetic diversity was calculated using the "picante" package in R. Before the two-way ANOVA, the Shapiro-Wilk test was used to test normal distribution and Levene's test was used to test homogeneity of variance. All data satisfied the assumptions of a two-way ANOVA. All analyses and tests were performed in R 3.5.3 software (R Core Team, Vienna, Austria) and the figures were finished using Origin 2019 (OriginLab Corporation, Northampton, MA, USA).

A structural equation model (SEM) was performed to infer the potential effects of environmental factors (slope position and soil properties) on AMF colonization and diversity. The interrelationships among the above variables were discovered by correlation analysis before the SEM procedure. Variables significantly associated with at least one other variable in correlation analysis were eligible for the subsequent SEM procedure [57]. SEM were constructed using AMOS 21 (IBM SPSS, Chicago, IL, USA).

The community composition of AMF refers to species abundance of each species in each plot, which is a multivariate dataset. The matrix-based dissimilarity assessment provides greater change of community composition than richness and the diversity index. Therefore, non-metric multi-dimensional scaling (NMDS) with the Bray-Curtis dissimilarity measurement and analysis of similarities (ANOSIM) (999 permutations, non-parametric) were used to examine the dissimilarities of the AMF community compositions among the plots [79]. Before the analysis of the AMF community composition, the abundance of OTUs was Hellinger-transformed to reduce the impact of rare OTUs [80]. The NMDS 
and ANOSIM were performed using the "vegan" statistical package in R 3.5.3. In addition, Venn diagrams were used to depict particular species and common species on different slope positions.

The Mantel test or partial Mantel test was used to detect the Mantel statistic as a matrix correlation between two dissimilarity matrices, namely community composition matrix and environmental factor matrix (999 permutations) [81]. Redundancy analysis (RDA) and canonical correspondence analysis (CCA) were used to investigate the relationships between the environmental factors and AMF community composition and to probe the principal environmental factors impacting the AMF community composition. Before RDA or CCA, detrended correspondence analysis (DAC) was performed to determine whether RDA or CCA should be chosen. If the axis length was bigger than 4, CCA should be performed; otherwise, RDA. The Mantel test and RDA were performed using the "vegan" statistical package in R 3.5.3. Prior to the above analysis, upper, middle, and lower slope positions were converted to the numerical values of 1,2, and 3, respectively. Aspect was transformed from the $0^{\circ}$ to $360^{\circ}$ compass scale to a value between 0 and 1 , with 0 indicating north-northeast directions and 1 indicating south-southwest directions [82]. The conversion was performed using the following formula:

$$
\text { TRASP }=\{1-\cos [(\pi / 180) *(\text { aspect }-30)]\} / 2
$$

\section{Results}

\subsection{Sequencing Analysis and Identification of the AMF}

After quality filtering and chimera removal, 1,670,493 fungal sequences were acquired from a total of 90 samples in this study. These sequences were clustered into 174 OTUs. Of these, 1,606,992 sequences belonged to Glomeromycotina (corresponding to $96.2 \%$ of the total), which were clustered into 83 OTUs. After seven OTUs (<10 reads) were removed from the dataset, 1,606,919 sequences remained. Finally, 76 OTUs were found representing AMF taxa. Rarefaction curves were constructed showing the amplicon sequencing depths in all samples. All of the rarefaction curves showed near saturation when the rarefaction reached 5362, indicating that the amount of sampling was sufficient to explore the majority of the sequence types (Figure 2). Among the final 76 AMF OTUs, 46 belonged to Glomus (frequency of 61\%), 14 belonged to Archaeospora (frequency of 19\%), 13 belonged to Acaulospora (frequency of 17\%), and one belonged to each of Diversispora, Gigaspora, and Scutellospora (Figure S1, Supplementary Materials). The representative sequences were submitted to GenBank with the accession numbers MK841334-MK841409.

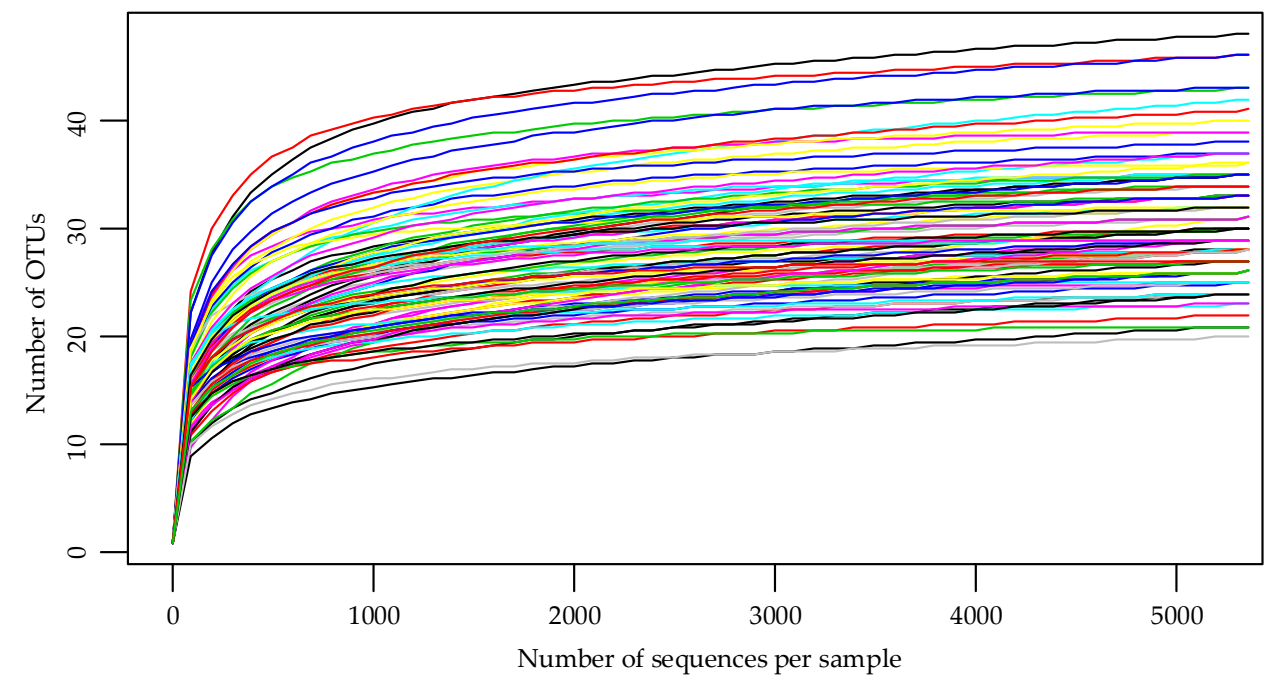

Figure 2. Rarefaction curves showing the amplicon sequencing depths in all samples. The number of observed operational taxonomic units (OTUs) was compared across samples when samples were rarefied at 5362 sequences. 


\subsection{AMF Colonization, Diversity, and Relational Environmental Factors}

There were significant differences in AMF colonization among different slope positions (Table 2). AMF colonization on the lower slope position was significantly higher than on the upper slope position (Figure 3), indicating there were more roots infected by AMF on the lower slope position than the upper.

There were significant differences in AMF diversity among slope positions (Table 2). The AMF richness, Shannon-Wiener index, and phylogenetic diversity on the upper slope position were significantly higher than on the middle and lower slope positions (Figure 3). In addition, phylogenetic diversity significantly differed among different thinning intensities, especially between $25 \%$ and $33 \%$ (Table 2, Figure 3). There was also an interaction effect on AMF richness, Shannon-Wiener index, and phylogenetic diversity with thinning intensity (Table 2). The differences in richness and phylogenetic diversity between the upper slope and the middle and lower slopes were greater on $25 \%$ and $33 \%$ thinning intensity than others (Figure 3). The difference in Shannon-Wiener index between the upper slope and the middle and lower slopes was greater on $25 \%$ thinning intensity than others (Figure 3 ). Hence, AMF diversity in the low or high thinning intensities was rather similar among different slope positions, whereas in the middle thinning intensity (25-33\%) AMF diversity was higher on the upper slope. Thinning intensity had no effect on AMF diversity (Table 2).

Table 2. Summary statistics of two-way ANOVA examining the effects of thinning intensity and slope position as well as their interaction on arbuscular mycorrhizal fungi (AMF) colonization and diversity.

\begin{tabular}{|c|c|c|c|c|c|}
\hline Variables & & Colonization & Richness & $\begin{array}{c}\text { Shannon-Wiener } \\
\text { Index }\end{array}$ & $\begin{array}{c}\text { Phylogenetic } \\
\text { Diversity }\end{array}$ \\
\hline \multirow{2}{*}{ Thinning intensity } & $\mathrm{F}$ & 1.824 & 1.143 & 0.735 & 2.881 \\
\hline & $P$ & 0.133 & 0.343 & 0.571 & $0.028^{*}$ \\
\hline \multirow{2}{*}{ Slope position } & $\mathrm{F}$ & 33.914 & 29.554 & 11.870 & 36.695 \\
\hline & $P$ & $<0.001^{* * *}$ & $<0.001^{* * *}$ & $<0.001^{* * *}$ & $<0.001^{* * *}$ \\
\hline \multirow{2}{*}{ Thinning intensity $\times$ slope position } & $\mathrm{F}$ & 0.538 & 2.515 & 3.859 & 2.376 \\
\hline & $P$ & 0.789 & $0.018^{*}$ & $0.001^{* *}$ & $0.024^{*}$ \\
\hline
\end{tabular}




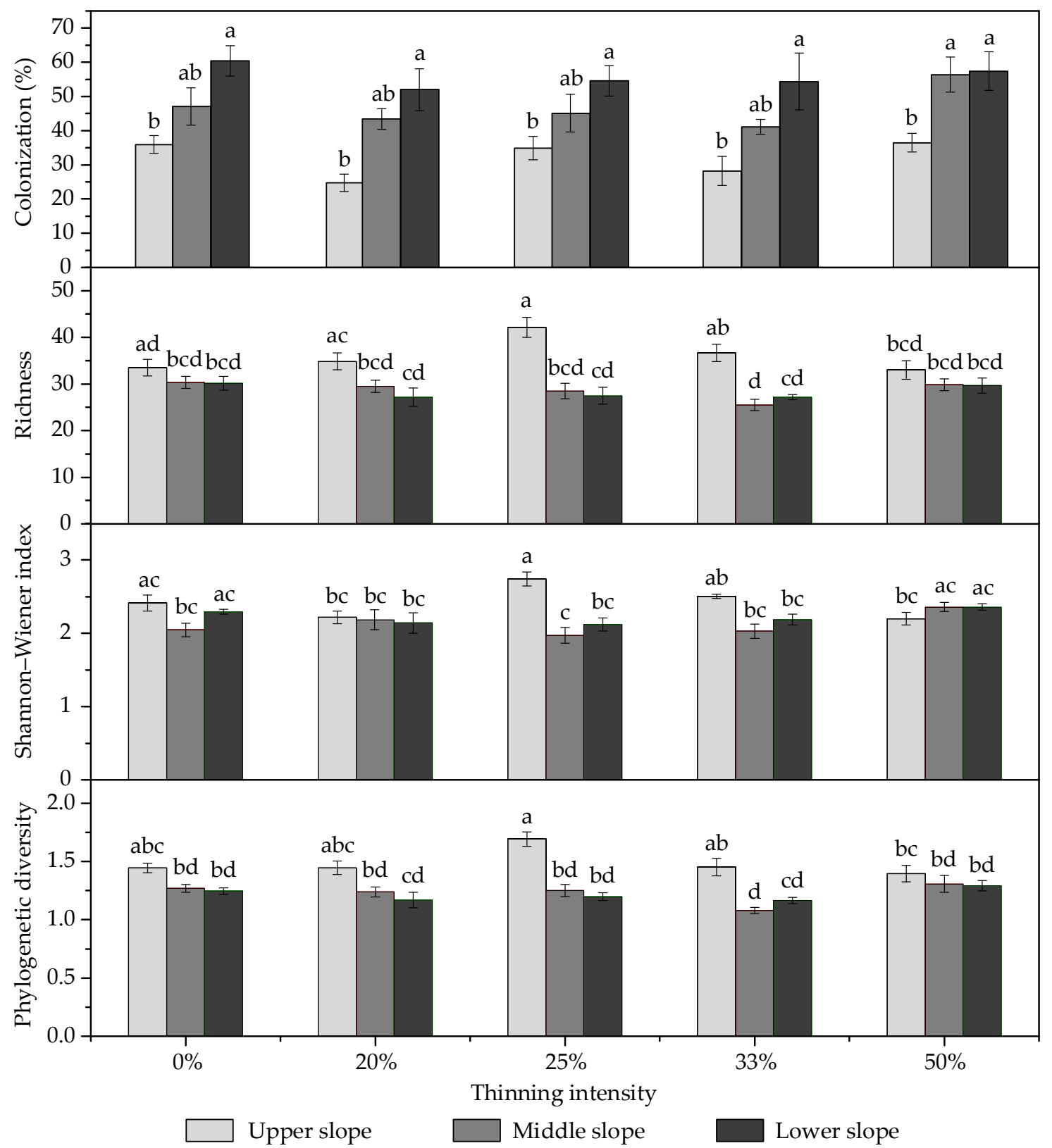

Figure 3. Differences of AMF colonization, richness, and diversity among slope positions and thinning intensities. Values are means \pm standard errors. Different letters indicate significant interactions or slope position main effects $(p<0.05)$ based on a two-way ANOVA followed by a Tukey's HSD multiple comparison test.

Soil properties among different slope positions and thinning intensities are shown in Table S2 (Supplementary Materials). Structural equation model (SEM) results allowed us to infer the possibly direct and indirect influences of slope position and soil properties on AMF colonization and diversity (Figure 4). Specifically, AMF colonization was positively correlated with slope position (path coefficient $=0.684$ ), and slope position significantly changed soil AK content (path coefficient $=0.225$ ), which had a substantial influence on AMF colonization (path coefficient $=0.252$ ). Furthermore, the slope position was the most considerable factor that directly affected AMF diversity (path coefficient $=-0.525$ ). 

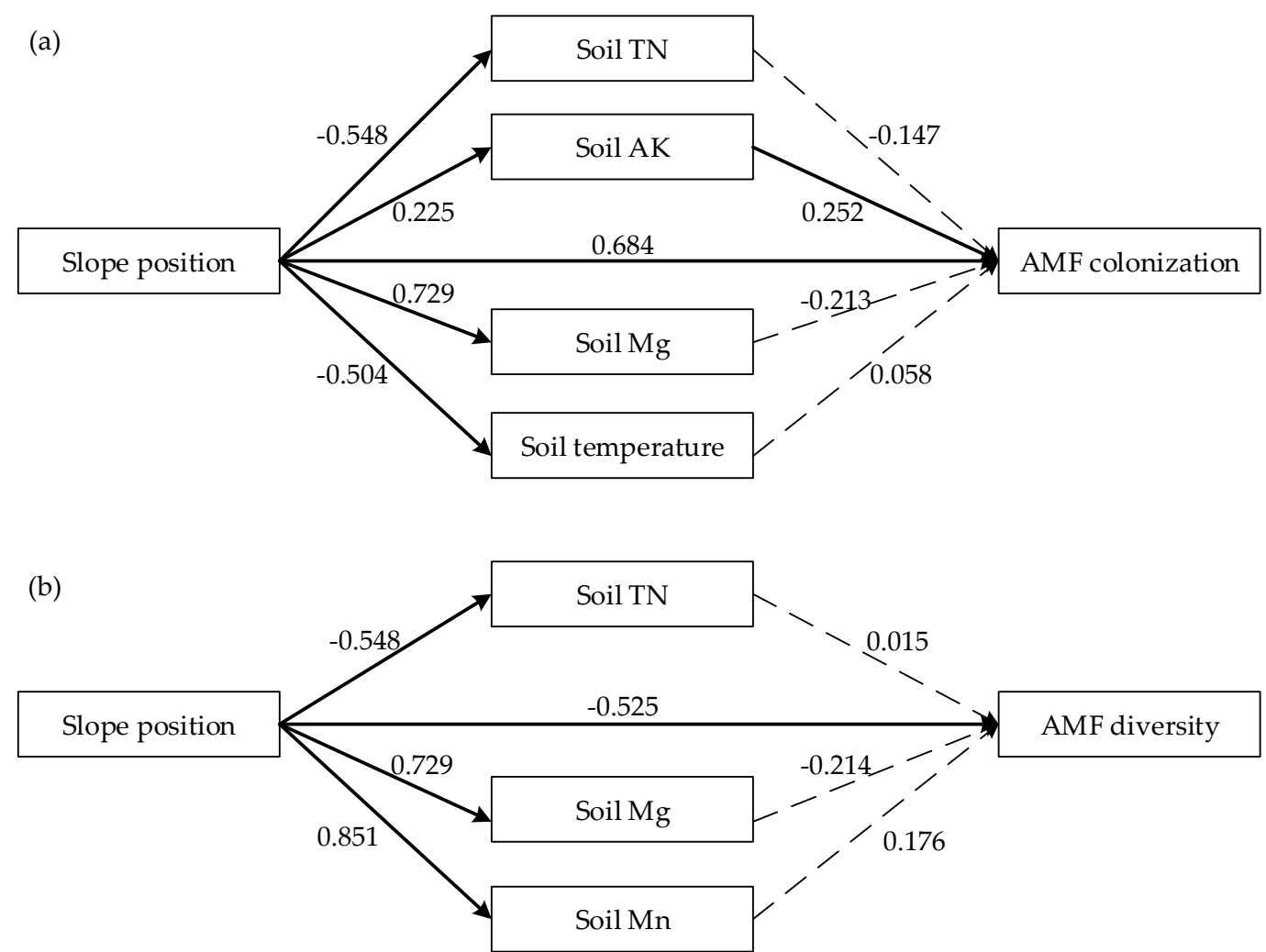

Figure 4. Structural equation model (SEM) results allow us to infer the plausible causal effects of slope position and soil factors on (a) AMF colonization and (b) diversity. Bold and dashed lines indicate significant and non-significant pathways, respectively. The final model fit the data well: (a) $\chi^{2}=13.676$, $d f=6, p=0.033$; AIC = 43.676; RMSE =0.120. (b) $\chi^{2}=13.282, d f=3, p=0.004 ;$ AIC $=37.28$; RMSE $=0.196$.

\subsection{AMF Community Composition}

NMDS ordination showed that the community composition of AMF was significantly different among different slope positions, especially between the upper and middle slopes and between the upper and lower slopes (Figure 5). Furthermore, the ANOSIM similarly showed that the differences between the upper and middle slope positions and between the upper and lower slope positions were highly significant $(p=0.001 ; p=0.001)$, whereas those of the middle and lower slopes position were significant $(p=0.016)$. In addition, unobvious separation of AMF communities from the different thinning intensities was observed, which indicated AMF communities were similar despite different thinning intensities (Figure 5). 


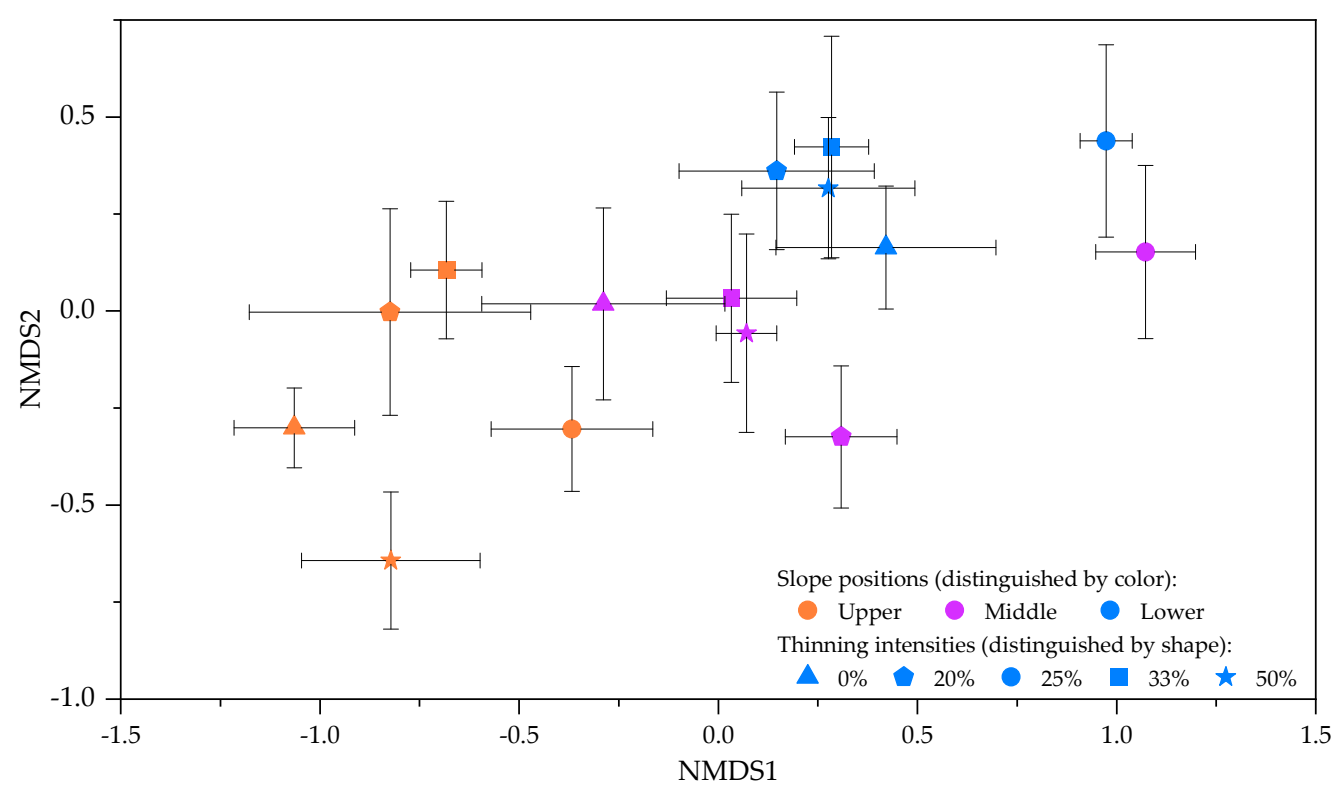

Figure 5. Non-metric multi-dimensional scaling (NMDS) ordinations of dissimilarities of AMF communities on different plots with the data of OTU composition (Bray-Curtis distance). Values are means \pm standard errors.

Further analysis on the community composition of AMF among different slope positions (Figure 6) showed that the genera Glomus, Archaeospora, Acaulospora, and Gigaspora appeared on all slope positions without significant differences $(p>0.05)$. Glomus was the most abundant genus of all slope positions, especially on the middle and lower slope positions with more than $80 \%$ relative abundance. The relative abundance of Diversispora was significantly different among slope positions $(p=0.028)$, with absolute dominance on the upper slope position. Scutellospora was the unique genus only presented on the upper slope position. Similarly, at the OTU level, there were four, none, and one unique taxa on the upper, middle, and lower slope positions, respectively (Figure 7). In addition, there were six and three common taxa on the upper and middle slope positions and on the middle and lower slope positions, respectively, whereas no common taxa occurred on the upper and lower slope positions (Figure 7).

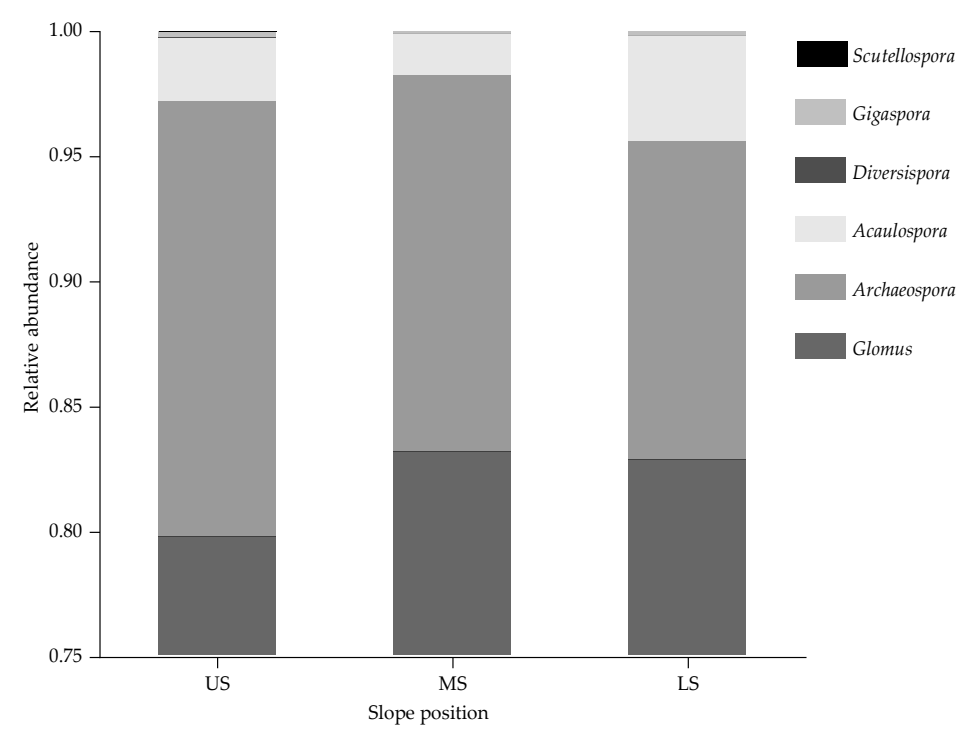

Figure 6. Abundance percentages of AMF genera for different slope positions. US: upper slope position; MS: middle slope position; LS: lower slope position. 


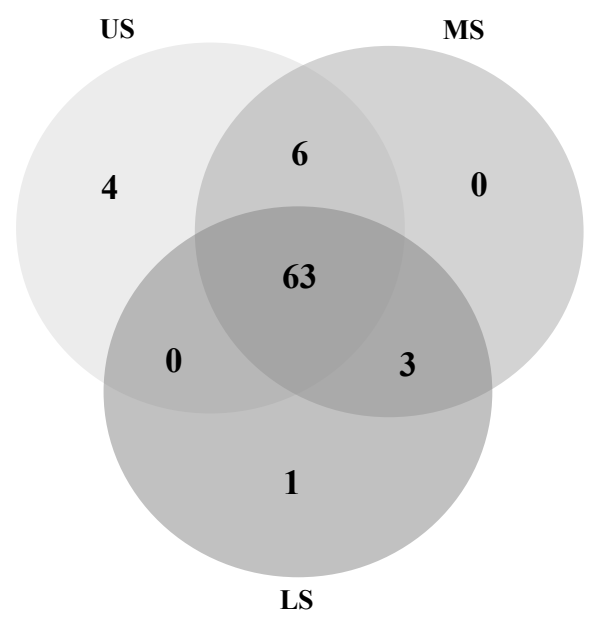

Figure 7. Venn diagram of AMF OTUs for different slope positions. US: upper slope position; MS: middle slope position; LS: lower slope position.

\subsection{Relationship between AMF Community Structure and Environmental Factors}

Partial Mantel test results confirmed that soil Mg content, soil Mn content, and soil temperature had a significantly positive correlation with AMF community composition at the OTU level (Table 3). CCA on the relative abundance of OTUs showed that these variables explained a total of $10.9 \%$ of the variance in the composition of AMF communities among plots, with Axis 1 explaining 9.2\% and Axis 2 explaining $1.7 \%$ of the total variation (Figure $8 \mathrm{a}$ ). When controlling other environmental factors, soil Mg content showed the strongest effect on AMF community composition $(p=0.001)$, whereas soil Mn content and soil temperature showed fewer but significant influences (Table 3). Soil Mg and Mn contents were the prominent factors which contributed to the AMF community distributions among the three slope positions, and the AMF community compositions on the middle and lower slopes were more relevant to soil temperature than on the upper slope (Figure 8a).

In addition, the RDA of AMF genera with edaphic factors showed that the variables explained $10.4 \%$ of the total variance, with Axis 1 explaining 8.3\% and Axis 2 explaining 2.1\% (Figure 8b). Figure $8 \mathrm{~b}$ showed that soil $\mathrm{pH}$ and total $\mathrm{N}$ content significantly positively related to Glomus, whereas $\mathrm{pH}$ and $\mathrm{Mg}$ content negatively related to Archaeospora. Slope position and soil Mn content significantly positively related to Acaulospora, whereas negatively related to Gigaspora. Soil available P was positively related to Diversispora.

Table 3. Relationships between AMF community compositions and environmental factors, as revealed by the partial Mantel test.

\begin{tabular}{ccc}
\hline \multirow{2}{*}{ Explanatory Variables } & \multicolumn{2}{c}{ OTU Level } \\
\cline { 2 - 3 } & $\mathbf{R}$ & $\boldsymbol{P}$ \\
\hline Soil $\mathrm{pH}$ & 0.036 & 0.162 \\
Soil organic carbon $\left(\mathrm{g} \mathrm{kg}^{-1}\right)$ & 0.061 & 0.080 \\
Soil total $\mathrm{N}\left(\mathrm{g} \mathrm{kg}^{-1}\right)$ & 0.043 & 0.130 \\
Soil total $\mathrm{P}\left(\mathrm{g} \mathrm{kg}^{-1}\right)$ & 0.053 & 0.108 \\
Soil available $\mathrm{N}\left(\mathrm{mg} \mathrm{kg}^{-1}\right)$ & -0.054 & 0.910 \\
Soil available $\mathrm{P}\left(\mathrm{mg} \mathrm{kg}^{-1}\right)$ & 0.032 & 0.189 \\
Soil available $\mathrm{K}\left(\mathrm{mg} \mathrm{kg}^{-1}\right)$ & -0.056 & 0.917 \\
Soil Mg $\left(\mathrm{mg} \mathrm{kg}^{-1}\right)$ & 0.147 & $0.001 * *$ \\
Soil Mn $\left(\mathrm{mg} \mathrm{kg}^{-1}\right)$ & 0.076 & $0.012 *$ \\
Soil temperature $\left({ }^{\circ} \mathrm{C}\right)$ & 0.073 & $0.030^{*}$ \\
\hline
\end{tabular}



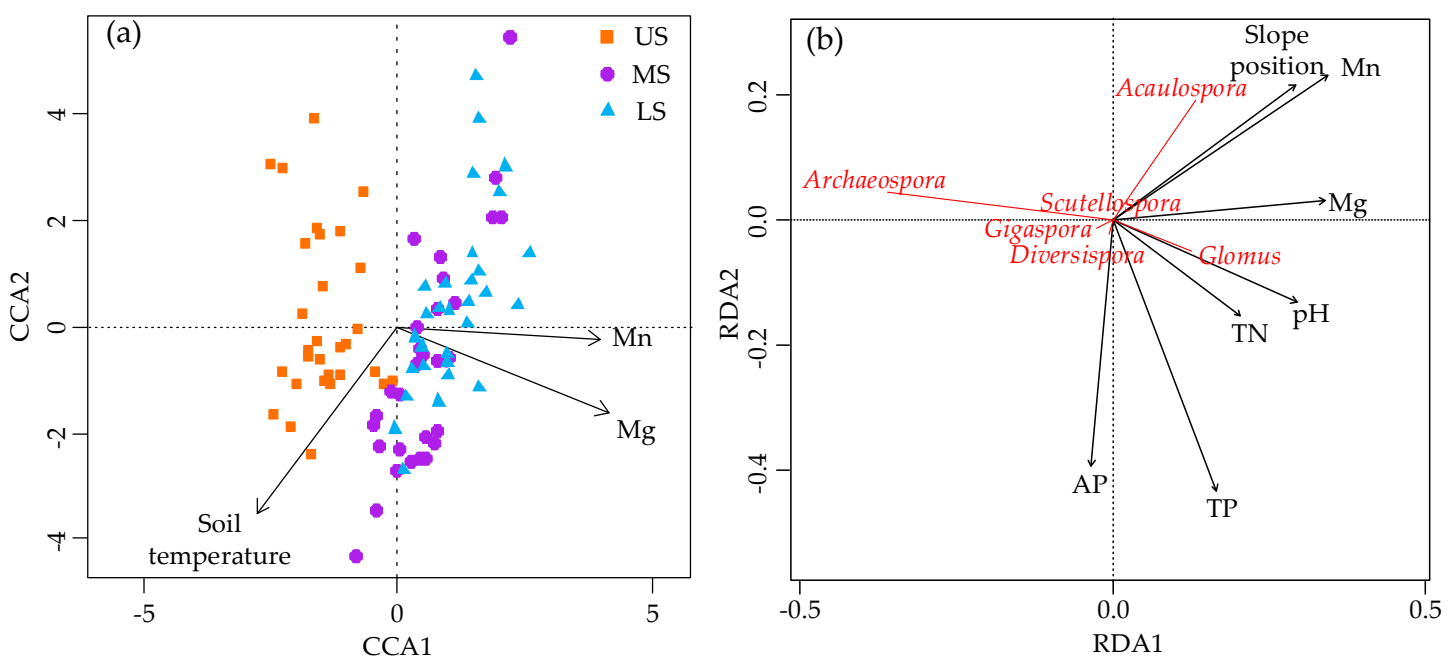

Figure 8. Canonical correspondence analysis (CCA) ordinations of dissimilarities of (a) OTUs' relative abundance among samples with edaphic factors and redundancy analysis (RDA) ordinations of dissimilarities of (b) AMF genera with environmental factors.

\subsection{Relationship between AMF and Tree Growth}

Correlation analysis indicated that thinning intensity was positively correlated with the mean increment of individual DBH $(r=0.415 ; p<0.001)$.

\section{Discussion}

Our research found that the slope position, but not thinning, had significant effects on the colonization, diversity, and community composition of AMF in Chinese fir plantations, as well as had interaction with thinning intensity on diversity. Moreover, thinning practice was found to be capable of enhancing the growth of Chinese fir. These findings have practical relevance for forest management, particularly for optimizing silviculture and fertilization, in Chinese fir plantations.

Our findings highlight that AMF colonization on the lower slope position was significantly higher than on the upper slope position (Figure 3). This may be due to differences of edaphic factors among slope positions. P was regarded as the closest soil nutrients associated with mycorrhizal formation, playing an important role in regulating the colonization of AMF. Many studies have reported that colonization was potentially higher in the soils where the soil available phosphorus was lower, because host plants need more AMF uptake the nutrients from soil $[23,46,83,84]$. However, in this study, the influence of $\mathrm{P}$ was not recorded. Previous studies also found that $\mathrm{P}$ application had no or little effect on AMF root colonization $[85,86]$, which is in agreement with our findings. The possible explanation is that AMF colonization is closely associated with the $\mathrm{N}$ or other nutrients [86]. In this study, the correlation between AMF colonization and soil phosphorus content was negligible, whereas the correlation between AMF colonization and available K was significant. Moreover, phosphorus is generally deficient in our study area, so it could be ecologically significant to acquire phosphorus through more AMF colonization for Chinese fir and, consequently, for the optimization of fertilization. In our study, soil available $\mathrm{K}$ was a significant factor that increased AMF colonization. This result was found to be in good agreement with a previous related study, in which a significant and positive correlation was observed between AMF colonization and soil K [87]. However, its underlying reason needs further research. In addition, our study also found that AMF colonization was directly positively affected by slope position. The reasons may be with regard to spore density, soil moisture content, or other potential factors $[24,83,88]$.

Our study revealed that AMF diversity was higher on the upper slope position than on the middle and lower slope positions (Figure 3). The reason underlying this observation may be due to the fact that there was more sufficient light on the upper slope, which improves photosynthesis of plants and 
carbohydrate allocation to AMF $[89,90]$, thereby promoting more species to survive and subsequently increasing the diversity on the upper slope. Moreover, there was also an interaction between slope position and thinning intensity on AMF diversity. AMF diversity in the low or high thinning intensities was rather similar among different slope position, whereas in the middle thinning intensity it was higher on the upper slope (Figure 3). The intermediate disturbance hypothesis could explain this, that is, the maximum species richness is found at intermediate levels of disturbance [91].

Our findings indicated that AMF community compositions on different slope positions were distinct (Figure 5). Generally, local-scale AMF community compositions were determined by edaphic conditions and the differential survival strategies of AMF [24,92]. Thus, altered habitat and resource allocation may influence AMF community composition [93]. In our study, soil Mg and Mn contents were the prominent factor which contributed to the AMF community distributions among the three slope positions (Table 3, Figure 8a). The explanation may be that soil Mg and Mn contents were higher on the lower slope position than on the upper slope position, and higher soil nutrients should enable the occurrence of more AMF species on the lower slope position because only some species with higher competitive strategy can survive on the soil with low nutrients [94,95]. In addition, soil temperature significantly affected the community compositions of AMF by stimulating the supply of plant carbon for AMF, that is, lower temperatures restricting the allocation of plant carbon to fungi and species with a competitive strategy appearing in the soils with lower temperature [96-98].

Furthermore, different effects of the edaphic factors on AMF genera may be the differential survival strategies of the particular AMF genus. For example, the genera Gigaspora and Archaeospora show traits associated with a competitive strategy, namely the higher carbon acquisition from their host plants and higher nutrient acquisition from the soil, whereas the genera Glomus and Acaulospora are known to have a ruderal strategy or stress-tolerant strategy with low carbon and nutrient acquisition [99], which explains the opposite influences of soil available nutrient contents on them (Figure 8b). We also found that soil $\mathrm{pH}$ had a positive influence on Glomus and a negative influence on Archaeospora. Previous studies have shown that in acidic (low $\mathrm{pH}$ ) soils higher $\mathrm{pH}$ promotes the availability of various soil nutrients [92,100], thereby having a positive or negative influence on either Glomus or Archaeospora associated with different strategies in our study area ( $\mathrm{pH}$ was between 4.2 and 4.5).

Our research showed that thinning intensity had no significant effects on the colonization, diversity, and community compositions of AMF in Chinese fir plantations (Table 2). Previous studies have proven that thinning could enhance the growth of reserved trees by improving growth space and light transmittance in stands, as well as the development of the understory, which increases litter decomposition, available soil nutrients, and soil microorganisms [12,18,19]. However, thinning may affect soil properties in the long term due to changes in litter decomposition and nutrient status $[1,15]$. Hence, in our study, changes in soil properties over a short time (two years after thinning) were not significant and resulted in quite similar AMF despite the thinning intensity used. The impacts of thinning on AMF in the short term may not be as important as thinning in the management of Chinese fir plantations; however, the longer-term effects of thinning on AMF may require further research.

In our study, there was one plot of each thinning intensity on each slope position without replicated plots. Thus, the study serves as a specific case for Chinese fir and replicated studies could infer results across a larger landscape scale. Despite this, the results are consistent among repeated sampling of root samples from several trees, that is, there were six repetitions from each plot (thinning intensity and slope position). Although this study was conducted on one slope and in a small area during only one year, the results are instructive for forestry researchers and managers to understand that slope position should be considered in the management of Chinese fir plantations in hilly areas. For instance, adding AMF might be an alternative approach to chemical fertilization, promoting the growth of trees and reducing the environmental pollution caused by chemical fertilization. In addition, both chemical fertilization and the addition of AMF should be targeted to plantations on upper slopes because of fewer AMF spores and lower AMF colonization in those positions. Future research should focus on 
long-term continuous observations and be conducted in more numerous and wider areas and include other commercially important tree species.

\section{Conclusions}

This is the first study to explore AMF community composition at both the taxonomic unit level and the genus level on different slope positions in southern China. Our research showed that altitudinal slope position had significant effects on the colonization, diversity, and community composition of AMF in Chinese fir plantations. In addition, the interaction between slope position and thinning intensity had significant effects on AMF diversity. Moreover, thinning practice was found to enhance the growth of Chinese fir. Colonization of AMF had a significant increase from the top to the bottom of the slope, while AMF diversity on the upper slope position was obviously higher than on the lower slope position. Glomus was the most abundant genus in all slope positions, especially on the middle and lower slope positions. The relative abundance of Diversispora differed among slope positions, having absolute dominance on the upper slope position. Scutellospora was uniquely found on the upper slope position. Furthermore, soil Mg and Mn contents and soil temperature positively affected AMF community composition at the OTU level. These findings suggested that slope position should be considered in the management of Chinese fir plantations in hilly areas, and it may be an important consideration for forest management activities, especially when the optimization of silviculture and fertilization is concerned. For instance, adding AMF might replace chemical fertilization, promoting the growth of trees and reducing the environmental pollution caused by chemical fertilization. In addition, both chemical fertilization and the addition of AMF should be conducted more strongly on the upper slope position.

Supplementary Materials: The following are available online at http://www.mdpi.com/1999-4907/11/3/273/s1, Figure S1: Phylogenetic tree created by representative sequences of each AMF OTU identified from this study and referenced sequences from the GenBank database. Table S1: Description of the barcode sequences. Table S2: Soil properties on different plots.

Author Contributions: Conceptualization, X.X., X.W. and J.R; Methodology, X.X., M.C., P.W. and N.L.; Software, X.X. and P.W.; Validation, X.X., X.W. and Y.S.; Investigation, X.X. and N.L.; Writing-Original Draft Preparation, X.X.; Writing-Review \& Editing, X.W., M.C., Y.S. and J.R.; Supervision, X.W. and Y.S.; Project Administration, X.W.; Funding Acquisition, X.W. All authors have read and agreed to the published version of the manuscript.

Funding: This work was supported by the "National Natural Science Foundation of China: Study on crown models for Larix olgensis based on tree growth" project (No. 31870620), the "National Key Research \& Development (R\&D) Program of China: tending regeneration technique of spruce-fir forest" project (2017YFC050410101), and the "Short-term International Student Program for Postgraduates of Forestry First-Class Discipline" project (2019XKJS0501).

Acknowledgments: We acknowledge all those who were involved in the hard work of field data collection and who helped us in writing the paper. We appreciate the contribution of Peng Zhang who established the thinning experiments. We also acknowledge the use of the facilities at the Centre Experiment and Teaching, College of Forestry, Beijing Forestry University, Beijing, China.

Conflicts of Interest: The authors declare no conflict of interest.

\section{References}

1. Zhou, L.L.; Cai, L.P.; He, Z.M.; Wang, R.W.; Wu, P.F.; Ma, X.Q. Thinning increases understory diversity and biomass, and improves soil properties without decreasing growth of Chinese fir in southern China. Environ. Sci. Pollut. R 2016, 23, 24135-24150. [CrossRef] [PubMed]

2. SFA (State Forestry Administration of Forest Resources Management). The 8th National Forest Resources Inventory and the Status of Forest Resources; Forest Resources Management: Beijing, China, 2014; p. 90.

3. Sheng, W.T. On the maintenance of long-term productivity of plantation in China. For. Res. 2018, 1, 1-14.

4. Ma, L.Y.; Li, C.Y.; Wang, X.Q. Effects of thinning on the growth and the diversity of undergrowth of Pinus tabulaeformis plantation in Beijing mountainous areas. Sci. Silvae Sin. 2007, 43, 1-9. 
5. Raunikar, R.; Buongiorno, J.; Turner, J.A.; Zhu, S.S.; Perezgarcia, J. Global outlook for wood and forests with the bioenergy demand implied by scenarios of the Intergovernmental Panel on Climate Change. For. Policy Econ. 2010, 12, 48-56. [CrossRef]

6. Lindgren, P.M.F.; Sullivan, T.P. Influence of stand thinning and repeated fertilization on plant community abundance and diversity in young lodgepole pine stands: 15-year results. For. Ecol. Manag. 2013, 308, 17-30. [CrossRef]

7. Savill, P.; Evans, J.; Auclair, D.; Falck, J. Plantation Silviculture in Europe; Oxford university press: Oxford, UK, 1997; p. 308.

8. Sheng, W.T. Studies on density management and long-term productivity of Cunninghamia lanceolata forests. Sci. Silvae Sin. 2001, 37, 2-9.

9. Tian, D.L.; Xiang, W.H.; Chen, X.Y.; Yan, W.D.; Fang, X.; Kang, W.X.; Dan, X.W.; Peng, C.H.; Peng, Y.Y. A long-term evaluation of biomass production in first and second rotations of Chinese fir plantations at the same site. Forestry 2011, 84, 411-418. [CrossRef]

10. Wen, Y.G.; Cheng, F.; Liu, S.R. Relationship between species diversity and biomass of Eucalyptus plantation in Guangxi. Sci. Silvae Sin. 2008, 44, 14-19. [CrossRef]

11. Ares, A.; Neill, A.R.; Puettmann, K.J. Understory abundance, species diversity and functional attribute response to thinning in coniferous stands. For. Ecol. Manag. 2010, 260, 1104-1113. [CrossRef]

12. Chen, X.L.; Wang, D.; Chen, X.; Wang, J.; Diao, J.J.; Zhang, J.Y.; Guan, Q.W. Soil microbial functional diversity and biomass as affected by different thinning intensities in a Chinese fir plantation. Appl. Soil Ecol. 2015, 92, 35-44. [CrossRef]

13. Trentini, C.P.; Campanello, P.I.; Villagra, M.; Ritter, L.; Ares, A.; Goldstein, G. Thinning of loblolly pine plantations in subtropical Argentina: Impact on microclimate and understory vegetation. For. Ecol. Manag. 2017, 384, 236-247. [CrossRef]

14. Taki, H.; Inoue, T.; Tanaka, H.; Makihara, H.; Sueyoshi, M.; Isono, M.; Okabe, K. Responses of community structure, diversity, and abundance of understory plants and insect assemblages to thinning in plantations. For. Ecol. Manag. 2010, 259, 607-613. [CrossRef]

15. Dang, P.; Gao, Y.; Liu, J.L.; Yu, S.C.; Zhao, Z. Effects of thinning intensity on understory vegetation and soil microbial communities of a mature Chinese pine plantation in the Loess Plateau. Sci. Total Environ. 2018, 630, 171-180. [CrossRef] [PubMed]

16. Yao, M.H.; Sheng, W.T.; Xiong, Y.Q. Study on the influence of undergrowth vegetation on the soil fertility of Chinese fir. For. Res. 1991, 3, 247-251.

17. He, F.L.; Barclay, H.J. Long-term response of understory plant species to thinning and fertilization in a Douglas-fir plantation on southern Vancouver Island, British Columbia. Can. J. For. Res. 2000, 30, 566-572. [CrossRef]

18. Teste, F.P.; Lieffers, V.J.; Strelkov, S.E. Ectomycorrhizal community responses to intensive forest management: thinning alters impacts of fertilization. Plant Soil 2012, 360, 333-347. [CrossRef]

19. Yang, B.; Pang, X.Y.; Hu, B.; Bao, W.K.; Tian, G.L. Does thinning-induced gap size result in altered soil microbial community in pine plantation in eastern Tibetan Plateau? Ecol. Evol. 2017, 7, 2986-2993. [CrossRef]

20. Lee, B.; Eo, S.H. Metagenomic approach revealed effects of forest thinning on bacterial communities in the forest soil of Mt. Janggunbong, South Korea. J. Mt. Sci.-Engl. 2018, 15, 59-67. [CrossRef]

21. Xiao, W.; Fei, F.; Diao, J.; Chen, B.J.W.; Guan, Q. Thinning intensity affects microbial functional diversity and enzymatic activities associated with litter decomposition in a Chinese fir plantation. J. For. Res. 2017. [CrossRef]

22. Lin, W.R.; Wang, P.H.; Chen, W.C.; Lai, C.M.; Winder, R.S. Responses of soil fungal populations and communities to the Thinning of Cryptomeria Japonica forests. Microbes Environ. 2016, 31, 19-26. [CrossRef]

23. Li, L.F.; Zhang, Y.; Zhao, Z.W. Arbuscular mycorrhizal colonization and spore density across different land-use types in a hot and arid ecosystem, Southwest China. J. Plant Nutr. Soil. Sc. 2010, 170, 419-425. [CrossRef]

24. Birhane, E.; Aregawi, K.; Giday, K. Changes in arbuscular mycorrhiza fungi spore density and root colonization of woody plants in response to exclosure age and slope position in the highlands of Tigray, Northern Ethiopia. J. Arid Environ. 2017, 142, 1-10. [CrossRef] 
25. Van der Heijden, M.G.A.; Klironomos, J.; Ursic, M.; Moutoglis, P.; Streitwolf-Engel, R.; Boller, T.; Wiemken, A.; Sanders, I.R. Mycorrhizal fungal diversity determines plant biodiversity, ecosystem variability and productivity. Nature 1998, 396, 69-72. [CrossRef]

26. Liang, Y.; Su, Y.; He, X.; Chen, X.; Hu, Y. Various effects on the Abundance and Composition of Arbuscular Mycorrhizal Fungal Communities in Soils in Karst Shrub Ecosystems. Environ. Sci. 2017, 38, 4828-4835.

27. Seibert, J.; Stendahl, J.; Sørensen, R. Topographical influences on soil properties in boreal forests. Geoderma 2007, 141, 139-148. [CrossRef]

28. Mohammadi, M.F.; Jalali, S.; Kooch, Y.; Said-Pullicino, D. Slope gradient and shape effects on soil profiles in the northern mountainous forests of Iran. Eurasian Soil Sci. 2016, 49, 1366-1374. [CrossRef]

29. Fisk, M.C.; Schmidt, S.K.; Seastedt, T.R. Topographic patterns of above- and belowground production and nitrogen cycling in alpine tundra. Ecology 1998, 7, 2253-2266. [CrossRef]

30. Xiao, Y.; Yang, L.; Nie, X.; Li, C.; Xiong, F.; Wang, L.; Zhou, G. Effects of slope position on phylogenetic diversity and community structure of alpine shrub community. Chin. J. Ecol. 2019, 38, 1611-1619. [CrossRef]

31. Yang, Y.C.; Liang Jun, D.A.; You, W.H. Vegetation structure in relation to micro-landform in Tiantong National Forest Park, Zhejiang, China. Acta Ecol. Sin. 2005, 25, 2830-2840.

32. Yang, Y. A brief review for studies on differentiation of vegetation pattern along a topographic gradient in hilly regions. J. Plant Ecol. 2006.

33. Zhou, P.; Liu, G.; Hou, X. Biomass and species diversity of herbosa at different position and aspects of slope in the Hilly-gully Region of Loess Plateau. Sci. Soil Water Conserv. 2009, 7, 67-73.

34. Zhang, D.; Zhang, Y.; Qu, Y.; Ma, K.; Dai, S. Effects of slope position on soil microbial biomass of Quercus liaotungensis forest in Dongling Mountain. Acta Ecol. Sin. 2012, 32, 6412-6421. [CrossRef]

35. Leblanc, N.; Kinkel, L.L.; Kistler, H.C. Soil Fungal Communities Respond to Grassland Plant Community Richness and Soil Edaphics. Microb. Ecol. 2015, 70, 188-195. [CrossRef] [PubMed]

36. Schlatter, D.C.; Kahl, K.; Carlson, B.; Huggins, D.R.; Paulitz, T. Fungal community composition and diversity vary with soil depth and landscape position in a no-till wheat-based cropping system. Microb. Ecol. 2018, 94, 1-15. [CrossRef]

37. Bennie, J.; Hill, M.O.; Baxter, R.; Huntley, B. Influence of Slope and Aspect on Long-Term Vegetation Change in British Chalk Grasslands. J. Ecol. 2006, 94, 355-368. [CrossRef]

38. Lei, S.Y.; Zhao, W.H.; Yang, Y.H.; Lv, D.; Bai, Y.B.; He, L.; Guo, J.W.; Zhang, X.P. Spatial Distribution Characteristics of Soil Nutrients and Vegetation Growth Status in Different Slopes. Res. Soil Water Conserv. 2018, 26, 1-7.

39. Zhang, Q.; Niu, J.; Buyantuyev, A.; Han, F.; Dong, J.; Zhang, Y.; Kang, S.; Yang, Y. Vegetation differentiation and soil effect at different slope locations-A case study of Stipa breviflora grassland in Inner Mongolia, China. Chin. J. Plant Ecol. 2011, 35, 1167-1181. [CrossRef]

40. Jiang, X.G. Mixed afforestation effects analysis of bamboo and fir in different aspects and slope positions. J. Fujian For. Sci. Tech. 2013, 40, 8-11.

41. Zhang, M.; Xie, Z.; Xiong, G.; Fan, D. Structures and topographical pattern of the tree layer of Fagus engleriana-Cyclobalanopsis oxyodon community in Shennongia area, Hubei Province, China. Front. Biol. 2009, 4, 503-512. [CrossRef]

42. Spatafora, J.W.; Chang, Y.; Benny, G.L.; Lazarus, K.; Smith, M.E.; Berbee, M.L.; Bonito, G.; Corradi, N.; Grigoriev, I.; Gryganskyi, A.; et al. A phylum-level phylogenetic classification of zygomycete fungi based on genome-scale data. Mycologia 2016, 108, 1028-1046. [CrossRef]

43. Alexander, H.M. Fungal pathogens and the structure of plant populations and communities. Mycology 1991, $16,423-432$.

44. Hodge, A.; Storer, K. Arbuscular mycorrhiza and nitrogen: implications for individual plants through to ecosystems. Plant Soil 2015, 386, 1-19. [CrossRef]

45. Xiang, D.; Verbruggen, E.; Hu, Y.; Veresoglou, S.D.; Rillig, M.C.; Zhou, W.; Xu, T.; Li, H.; Hao, Z.; Chen, Y.; et al. Land use influences arbuscular mycorrhizal fungal communities in the farming-pastoral ecotone of northern China. New Phytol. 2014, 204, 968-978. [CrossRef] [PubMed]

46. Hill, J.O.; Simpson, R.J.; Ryan, M.H.; Chapman, D.F. Root hair morphology and mycorrhizal colonisation of pasture species in response to phosphorus and nitrogen nutrition. Crop Pasture Sci. 2010, 61, 122-131. [CrossRef] 
47. Hodge, A.; Helgason, T.; Fitter, A.H. Nutritional ecology of arbuscular mycorrhizal fungi. Fungal Ecol. 2010, 3, 267-273. [CrossRef]

48. Augé, R.M. Water relations, drought and vesicular-arbuscular mycorrhizal symbiosis. Mycorrhiza 2001, 11, 3-42. [CrossRef]

49. Garg, N.; Chandel, S. Effect of mycorrhizal inoculation on growth, nitrogen fixation, and nutrient uptake in Cicer arietinum (L.) under salt stress. Turk. J. Agric. For. 2011, 35, 205-214. [CrossRef]

50. Pozo, M.J.; Azcón-Aguilar, C. Unraveling mycorrhiza-induced resistance. Curr. Opin. Plant Biol. 2007, 10, 393-398. [CrossRef]

51. Smith, S.E.; Read, D.J. Mycorrhizal Symbiosis, 3rd ed.; Academic Press: London, UK, 2008; p. 768.

52. Munkvold, L.; Kjoller, R.M.; Rosendahl, S.; Jakobsen, I. High functional diversity within species of arbuscular mycorrhizal fungi. New Phytol. 2010, 164, 357-364. [CrossRef]

53. Veresoglou, S.D.; Shaw, L.J.; Hooker, J.E.; Sen, R. Arbuscular mycorrhizal modulation of diazotrophic and denitrifying microbial communities in the (mycor)rhizosphere of Plantago lanceolata. Soil Biol. Biochem. 2012, 53, 78-81. [CrossRef]

54. Cheng, L.; Booker, F.L.; Tu, C.; Burkey, K.O.; Zhou, L.; Shew, H.D.; Rufty, T.W.; Hu, S. Arbuscular mycorrhizal fungi increase organic carbon decomposition under elevated $\mathrm{CO}_{2}$. Science 2012, 337, 1084. [CrossRef] [PubMed]

55. Leifheit, E.F.; Verbruggen, E.; Rillig, M.C. Arbuscular mycorrhizal fungi reduce decomposition of woody plant litter while increasing soil aggregation. Soil Biol. Biochem. 2015, 81, 323-328. [CrossRef]

56. Rillig, M.C.; Mummey, D.L. Mycorrhizas and soil structure. New Phytol. 2010, 171, 41-53. [CrossRef] [PubMed]

57. Kim, Y.; Gao, C.; Zheng, Y.; He, X.; Yang, W.; Chen, L.; Wan, S.; Guo, L. Arbuscular mycorrhizal fungal community response to warming and nitrogen addition in a semiarid steppe ecosystem. Mycorrhiza 2015, 25, 267-276. [CrossRef] [PubMed]

58. Higo, M.; Kang, D.; Isobe, K. First report of community dynamics of arbuscular mycorrhizal fungi in radiocesium degradation lands after the Fukushima-Daiichi Nuclear disaster in Japan. Sci. Rep.-UK 2019, 9, 8210-8240. [CrossRef] [PubMed]

59. Higo, M.; Tatewaki, Y.; Gunji, K.; Kaseda, A.; Isobe, K. Cover cropping can be a stronger determinant than host crop identity for arbuscular mycorrhizal fungal communities colonizing maize and soybean. PeerJ 2019, 7, e6403. [CrossRef]

60. Li, L.; Zhou, G.; Liu, J.; Li, H. The resource investigation and community structure characteristics of mycorrhizal fungi associated with Chinese fir. Afr. J. Biotechnol. 2011, 10, 5719-5724. [CrossRef]

61. Li, L.; McCormack, M.L.; Chen, F.; Wang, H.; Ma, Z.; Guo, D. Different responses of absorptive roots and arbuscular mycorrhizal fungi to fertilization provide diverse nutrient acquisition strategies in Chinese fir. For. Ecol. Manag. 2019, 433, 64-72. [CrossRef]

62. Begum, N.; Qin, C.; Ahanger, M.A.; Raza, S.; Khan, M.I.; Ashraf, M.; Ahmed, N.; Zhang, L. Role of Arbuscular Mycorrhizal Fungi in Plant Growth Regulation: Implications in Abiotic Stress Tolerance. Front. Plant Sci. 2019, 10, 1068. [CrossRef]

63. Liu, Q.; Meng, S.; Zhou, H.; Zhou, G.; Li, Y. Tree Volume Tables of China; China Forestry Publishing House: Beijing, China, 2017; p. 1107.

64. Zhang, J.; Wang, F.; Che, R.; Wang, P.; Liu, H.; Ji, B.; Cui, X. Precipitation shapes communities of arbuscular mycorrhizal fungi in Tibetan alpine steppe. Sci. Rep.-UK 2016, 6. [CrossRef]

65. McGonigle, T.P.; Miller, M.H.; Evans, D.G.; Fairchild, G.L.; Swan, J.A. A new method which gives an objective measure of colonization of roots by vesicular-arbuscular mycorrhizal fungi. New Phytol. 1990, 115, 495-501. [CrossRef]

66. Azmat, M.A.; Khan, I.A.; Cheema, H.M.; Rajwana, I.A.; Khan, A.S.; Khan, A.A. Extraction of DNA suitable for PCR applications from mature leaves of Mangifera indica L. J. Zhejiang Univ. Sci. B 2012, 13, 239-243. [CrossRef] [PubMed]

67. Lu, N.; Xu, X.; Wang, P.; Zhang, P.; Ji, B.; Wang, X. Succession in arbuscular mycorrhizal fungi can be attributed to a chronosequence of Cunninghamia lanceolata. Sci. Rep. 2019, 9, 18057. [CrossRef] [PubMed]

68. Schwarzott, D.; Schüßler, A. A simple and reliable method for SSU rRNA gene DNA extraction, amplification, and cloning from single AM fungal spores. Mycorrhiza 2001, 10, 203-207. [CrossRef] 
69. Lee, J.; Lee, S.; Young, J.P. Improved PCR primers for the detection and identification of arbuscular mycorrhizal fungi. FEMS Microbiol. Ecol. 2008, 65, 339-349. [CrossRef]

70. Simon, L.; Lalonde, M.; Bruns, T.D. Specific amplification of $18 \mathrm{~S}$ fungal ribosomal genes from vesicular-arbuscular endomycorrhizal fungi colonizing roots. Appl. Environ. Microb. 1992, 58, 291-295. [CrossRef]

71. Sato, K.; Suyama, Y.; Saito, M.; Sugawara, K. A new primer for discrimination of arbuscular mycorrhizal fungi with polymerase chain reaction-denature gradient gel electrophoresis. Grassl. Sci. 2005, 51, 179-181. [CrossRef]

72. Magoc, T.; Salzberg, S.L. FLASH: fast length adjustment of short reads to improve genome assemblies. Bioinformatics 2011, 27, 2957-2963. [CrossRef]

73. Caporaso, J.G.; Kuczynski, J.; Stombaugh, J.; Bittinger, K.; Bushman, F.D.; Costello, E.K.; Fierer, N.; Pena, A.G.; Goodrich, J.K.; Gordon, J.I.; et al. QIIME allows analysis of high-throughput community sequencing data. Nat. Methods 2010, 7, 335-336. [CrossRef]

74. Edgar, R.C. UPARSE: highly accurate OUT sequences from microbial amplicon reads. Nat. Methods 2013, 10, 996-998. [CrossRef]

75. Hontoria, C.; García-González, I.; Quemada, M.; Roldán, A.; Alguacil, M.M. The cover crop determines the AMF community composition in soil and in roots of maize after a ten-year continuous crop rotation. Sci. Total Environ. 2019, 660, 913-922. [CrossRef] [PubMed]

76. Opik, M.; Zobel, M.; Cantero, J.J. Global sampling of plant roots expands the described molecular diversity of arbuscular mycorrhizal fungi. Mycorrhiza 2013, 23, 411-430. [CrossRef] [PubMed]

77. Bao, S. Soil and Agricultural Chemistry Analysis; China Agriculture Press: Beijing, China, 2000; p. 495.

78. Fierer, N.; Lauber, C.L.; Ramirez, K.S.; Zaneveld, J.; Bradford, M.A.; Knight, R. Comparative metagenomic, phylogenetic and physiological analyses of soil microbial communities across nitrogen gradients. ISME J. 2012, 6, 1007-1017. [CrossRef] [PubMed]

79. Oksanen, J.; Blanchet, F.G.; Kindt, R.; Legendre, P.; Minchin, P.R.; O’Hara, R.B.; Simpson, G.L.; Solymos, P.; Stevens, M.H.H.; Wagner, H.; et al. Vegan: Community ecology package. Available online: http://CRAN.Rproject.org/package=vegan (accessed on 2 March 2017).

80. Zheng, Y.; Kim, Y.C.; Tian, X.F.; Chen, L.; Yang, W.; Gao, C.; Song, M.H.; Xu, X.L.; Guo, L.D. Differential responses of arbuscular mycorrhizal fungi to nitrogen addition in a near pristine Tibetan alpine meadow. FEMS Microbiol. Ecol. 2014, 89, 594-605. [CrossRef] [PubMed]

81. Gao, C.; Kim, Y.; Zheng, Y.; Yang, W.; Chen, L.; Ji, N.; Wan, S.; Guo, L. Increased precipitation, rather than warming, exerts a strong influence on arbuscular mycorrhizal fungal community in a semiarid steppe ecosystem. Botany 2016, 94, 459-469. [CrossRef]

82. Yu, M.; Sun, O.J. Effects of forest patch type and site on herb-layer vegetation in a temperate forest ecosystem. For. Ecol. Manag. 2013, 300, 14-20. [CrossRef]

83. Songachan, L.S.; Lyngdoh, I.; Highland, K. Colonization of arbuscular mycorrhizal fungi in moderately degraded sub-tropical forest stands of Meghalaya, Northeast India. J. Agric. Technol. 2011, 6, 1673-1684.

84. Galvez, L.; Douds, D.D., Jr.; Drinkwater, L.E.; Wagoner, P. Effect of tillage and farming system upon VAM fungus populations and mycorrhizas and nutrient uptake of maize. Plant Soil 2001, 228, 299-308. [CrossRef]

85. Higo, M.; Sato, R.; Serizawa, A.; Takahashi, Y.; Gunji, K.; Tatewaki, Y.; Isobe, K. Can phosphorus application and cover cropping alter arbuscular mycorrhizal fungal communities and soybean performance after a five-year phosphorus-unfertilized crop rotational system? PeerJ 2018, 6, e4606. [CrossRef]

86. Higo, M.; Azuma, M.; Kamiyoshihara, Y.; Kanda, A.; Tatewaki, Y.; Isobe, K. Impact of Phosphorus Fertilization on Tomato Growth and Arbuscular Mycorrhizal Fungal Communities. Microorganisms 2020, 8, 178. [CrossRef]

87. Wang, J.; Wang, G.G.; Zhang, B.; Yuan, Z.; Fu, Z.; Yuan, Y.; Zhu, L.; Ma, S.; Zhang, J. Arbuscular mycorrhizal fungi associated with tree species in a planted forest of Eastern China. Forests 2019, 10, 424. [CrossRef]

88. Habiyaremye, J.D.D.; Muthuri, C.; Matiru, V.; Nyaga, J.; Mukuralinda, A.; Ruganzu, V.; Yoneda, M.; Sinclair, F. Occurrence and abundance of arbuscular mycorrhizal fungi (AMF) in agroforestry systems of Rubavu and Bugesera Districts in Rwanda. Afr. J. Microbiol. Res. 2015, 9. [CrossRef]

89. Chai, Y.; Jiang, S.; Guo, W.; Qin, M.; Pan, J.; Bahadur, A.; Shi, G.; Luo, J.; Jin, Z.; Liu, Y.; et al. The effect of slope aspect on the phylogenetic structure of arbuscular mycorrhizal fungal communities in an alpine ecosystem. Soil Biol. and Biochem. 2018, 126, 103-113. [CrossRef] 
90. Johnson, N.C.; Wilson, G.; Wilson, J.A.; Miller, R.M.; Bowker, M.A. Mycorrhizal phenotypes and the Law of the Minimum. New Phytol. 2015, 205, 1473-1484. [CrossRef]

91. Connell, J.H. Diversity in tropical rain forests and coral reefs. Science 1978, 199, 1302-1310. [CrossRef]

92. Vieira, L.C.; Da Silva, D.K.A.; de Melo, M.A.C.; Escobar, I.E.C.; Oehl, F.; Da Silva, G.A. Edaphic Factors Influence the Distribution of Arbuscular Mycorrhizal Fungi Along an Altitudinal Gradient of a Tropical Mountain. Microb. Ecol. 2019. [CrossRef]

93. Higo, M.; Isobe, K.; Yamaguchi, M.; Drijber, R.A.; Jeske, E.S.; Ishii, R. Diversity and vertical distribution of indigenous arbuscular mycorrhizal fungi under two soybean rotational systems. Biol. Fert. Soils 2013, 49, 1085-1096. [CrossRef]

94. Porras-Alfaro, A.; Herrera, J.; Natvig, D.O.; Sinsabaugh, R.L. Effect of long-term nitrogen fertilization on mycorrhizal fungi associated with a dominant grass in a semiarid grassland. Plant Soil 2007, 296, 65-75. [CrossRef]

95. Stover, H.J.; Naeth, M.A.; Boldt-Burisch, K. Soil disturbance changes arbuscular mycorrhizal fungi richness and composition in a fescue grassland in Alberta Canada. Appl. Soil Ecol. 2018, 131, 29-37. [CrossRef]

96. Heinemeyer, A.; Ridgway, K.P.; Edwards, E.J.; Benham, D.G.; Young, J.P.W.; Fitter, A.H. Impact of soil warming and shading on colonization and community structure of arbuscular mycorrhizal fungi in roots of a native grassland community. Glob. Chang. Biol. 2003, 10, 52-64. [CrossRef]

97. Hawkes, C.V.; Hartley, I.P.; Ineson, P.; Fitter, A.H. Soil temperature affects carbon allocation within arbuscular mycorrhizal networks and carbon transport from plant to fungus. Glob. Chang. Biol. 2008, 14, 1181-1190. [CrossRef]

98. Yang, W.; Zheng, Y.; Gao, C.; He, X.; Ding, Q.; Kim, Y.; Rui, Y.; Wang, S.; Guo, L. The arbuscular mycorrhizal fungal community response to warming and grazing differs between soil and roots on the Qinghai-Tibetan plateau. PLoS ONE 2013, 8, e76447. [CrossRef] [PubMed]

99. Chagnon, P.L.; Bradley, R.L.; Maherali, H.; Klironomos, J.N. A trait-based framework to understand life history of mycorrhizal fungi. Trends Plant Sci. 2013, 18, 484-491. [CrossRef] [PubMed]

100. Higo, M.; Higo, M.; Isobe, K.; Isobe, K.; Kang, D.; Kang, D.; Maekawa, T.; Maekawa, T.; Ishii, R.; Ishii, R. Molecular diversity and spore density of indigenous arbuscular mycorrhizal fungi in acid sulfate soil in Thailand. Ann. Microbiol. 2011, 61, 383-389. [CrossRef] 